\title{
COMPARISON OF Eucalypt, Pine, AND SUGARCANE CELLULOSE FIBERS USED FOR PAPER PRODUCTION
}

\author{
Isabela de Paula ${ }^{\circ}$, Adelsimara Ceballos Guerta ${ }^{3 *} \odot$, and Renata Miliani Martinez ${ }^{2}$
}

\author{
${ }^{1}$ Received on 27.03.2019 accepted for publication on 26.09.2019. \\ ${ }^{2}$ Universidade de Sorocaba,Faculdade deEngenharia Química,Sorocaba,SP- Brasil.E-mail: $<$ isabeladpaula@gmail.com> and $<$ renata. \\ martinez@prof.uniso.br>. \\ ${ }^{3}$ Universidade Estadual Paulista, Programa de Pós-Graduação em Ciências Ambientais, Sorocaba, SP - Brasil,. E-mail: <acguerta@ \\ hotmail.com>. \\ *Corresponding author.
}

\begin{abstract}
Sugarcane bagasse, a waste material generated by the sugar-alcohol industry, is rich in lignocellulosic components such as cellulose and hemicellulose. The bagasse can be employed as a raw material in the pulp and paper industry, but is currently rarely used for this purpose, due to the availability of traditional sources such as Eucalyptus and Pinus. The objective of this work was to compare the physical and mechanical properties of papers produced using the cellulose extracted from sugarcane, Eucalyptus, and Pinus by the Kraft method. Four paper samples were produced using cellulose obtained from the following fiber sources: (I) $100 \%$ sugarcane bagasse; (II) 100\% Eucalyptus; (III) 75\% Eucalyptus + 25\% Pinus; (IV) $75 \%$ sugarcane bagasse + $25 \%$ Pinus. Physical and mechanical tests were performed based on regulatory methodologies of the paper industry. The results indicated that the physical and mechanical characteristics of the paper produced from the sugarcane cellulose were similar to those of the traditional paper produced using Eucalyptus. Particular features such as good tearing resistance and tensile strength, as well as increased porosity and moisture, could be adjusted according to the intended use of the paper. Therefore, sugarcane bagasse can be considered a sustainable alternative to Eucalyptus and Pinus for the production of high quality paper, adding value to this agricultural residue.
\end{abstract}

Keywords: Lignocellulosic material; Paper sector; Kraft method.

\section{COMPARAÇÕES ENTRE AS FIBRAS DE CELULOSE DE Eucalipto, Pinheiro E DA CANA-DE-AÇÚCAR NA PRODUÇÃO DE PAPEL}

\begin{abstract}
RESUMO - O bagaço de cana-de-açúcar é um resíduo gerado da indústria sucroalcooleira, rico em componentes de materiais lignocelulósicos, como a celulose e hemicelulose. Estes podem ser empregados como matéria-prima no segmento de papel e celulose, porém pouco aplicados no ramo papeleiro pela disponibilidade das fontes tradicionais que são o Eucalyptus e Pinus. O objetivo desse trabalho foi comparar as propriedades fisicas e mecânicas dos papéis obtidos a partir da celulose extraída da cana-de-açúcar, Eucalyptus e Pinus pelo método Kraft. Foram utilizadas quatro amostras de papéis: celulose obtida 100\% de fibra de cana-deaçúcar (I), celulose obtida 100\% de fibra de Eucalyptus (II), 75\% celulose de Eucalyptus + 25\% celulose de Pinus (III) e $75 \%$ celulose de bagaço de cana-de-açúcar $+25 \%$ de celulose de Pinus (IV). Foram realizados testes fisicos e mecânicos de acordo com as metodologias que regulamentam o setor papeleiro. Os resultados indicam que o papel obtido a partir da celulose da cana-de-açúcar possui características fisicas e mecânicas semelhantes ao papel tradicional produzido com Eucalyptus. Características particulares como boa resistência ao rasgo e tração, maior porosidade e umidade podem ser ajustadas para adequar o papel dessa fonte ao seu uso apropriado. De modo geral, a celulose de cana-de-açúcar demonstra-se como uma opção frente ao uso do Eucalyptus e Pinus na obtenção de papéis de qualidade sustentável, tornando-se uma alternativa para a utilização de um resíduo agrícola.
\end{abstract}

Palavras-Chave: Lignocelulósicos; Setor papeleiro; Método kraft.

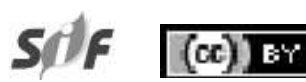

Revista Árvore 2019;43(4):e430411 http://dx.doi.org/10.1590/1806-90882019000400011 


\section{INTRODUCTION}

The production of pulp and paper is of global importance, due to the high demand for these materials by society. Increasing environmental concerns mean that it is essential to use renewable sources of cellulose, which has led to interest in methods that can use agricultural residues to obtain products with high added value (ARISP, 2018).

Brazil is one of the main producers of cellulose and paper and is globally competitive in this sector, with commercial forestry making an increasingly significant contribution to the Brazilian economy (Salles et al., 2011). In Brazil, the cellulose used for paper production is mainly obtained from the two plant species Eucalyptus and Pinus, depending on the desired characteristics of the final product (Miranda, 2008).

The cellulose obtained from Pinus (coniferous trees), classified as having long fibers, offers higher mechanical strength and porosity, so it is used for the manufacture of packaging, certificates, civil records, driver licenses, and other documents that require a long useful life (Castro, 2009). The cellulose extracted from Eucalyptus (a hardwood tree) is classified as having short fibers and accounts for $85 \%$ of the cellulose produced in Brazil (IBÁ, 2016). The properties of this type of cellulose are highly suitable for the manufacture of printing and writing paper, personal hygiene tissue, labels, and coating bases.

An attractive alternative to the traditional sources used for cellulose production is the fiber of sugarcane bagasse, which is generated in very large quantities in Brazil, since the country is the global leader in the production and marketing of sugar (DEPEC, 2017). The fibers of sugarcane bagasse contain a high percentage of cellulose, favoring the production of paper that is fully recyclable, which would contribute to reducing the quantities of waste discarded in the environment (ARISP, 2018).

Sugarcane has a low content of lignin, which is the component least desired by the paper industry, since a greater quantity of alkali is required in the delignification process, resulting in the degradation of carbohydrates and dissolution of low molecular weight polysaccharides. This reduces the yield, viscosity, and physical resistance of the pulp, while also generating a greater quantity of solids to burn in the boilers (Maranesi, 2010). Another factor in favor of the paper obtained from sugarcane bagasse is its low cost, since most recycled papers have high production costs, hence increasing the cost of the final product.

Sugarcane bagasse is a low cost byproduct that is widely available throughout most of the year. It can be used to produce high quality fiber that is versatile and suitable for diverse applications, while generating low quantities of undesirable chemical products (ARISP, 2018). In comparison of the amounts of cellulose, hemicellulose, and lignin in wood and sugarcane fibers, the values for Eucalyptus and Pinus are similar, although the fiber lengths are very different (longer for Pinus). The length of sugarcane bagasse fibers is similar to that of Eucalyptus fibers, being characterized as short fibers (Andrade et al., 2013).

In Brazil, commercial forestry may have several social and environmental implications (Borsato et al., 2010). In light of this, the aim of the present work was to compare the physical and mechanical properties of papers obtained from celluloses extracted by the Kraft method from forestry sources (Eucalyptus and Pinus) and sugarcane bagasse.

\section{MATERIALS AND METHODS}

\subsection{Types of cellulose and preparation of paper sheets}

The celluloses employed in the tests were extracted by the Kraft method and were supplied by the companies Fibria Papéis (Jacareí, São Paulo State) and GCE Papéis (São Paulo). The samples were coded using the numbers 1 (100\% Eucalyptus cellulose fibers), 2 (100\% sugarcane bagasse cellulose fibers), 3 (75\% Eucalyptus cellulose $+25 \%$ Pinus cellulose) and 4 (75\% sugarcane bagasse cellulose $+25 \%$ Pinus cellulose).

The paper sheets were prepared in accordance with the Associação Brasileira de Normas Técnicas (ABNT - NBR ISO) guideline 5269-1 (ABNT, 2006a). The as-received cellulose fibers were separated in water, with vigorous agitation using a hydrapulper, followed by addition of $20 \%(\mathrm{w} / \mathrm{w})$ calcium carbonate, $10 \%(\mathrm{w} / \mathrm{w})$ Hi-phase adhesive agent, and 10\% (w/w) aluminum sulfate. The resulting cellulosic mass was

Revista Árvore 2019;43(4):e430411 
transferred to the former, where excess water was drained, leaving only the fibrous fraction. Finally, the material was pressed and dried on a drying mat, until reaching a constant mass. All the subsequent analyses were performed under controlled conditions $\left(23{ }^{\circ} \mathrm{C}\right.$ and $50 \%$ relative humidity).

\subsection{Grammage and thickness measurements}

For grammage determination, the specimen was cut to a size of around $17 \times 17 \mathrm{~cm}$ and the area was calculated, followed by weighing it on a semianalytical balance with precision of $0.001 \mathrm{~g}$. The result was obtained as the mass of the sample divided by its area. The procedure was performed in triplicate. The methodology was according to the procedure described in ABNT NBR NM ISO 536 (ABNT, 2002). The grammages obtained in this analysis were used in the subsequent tests, since this parameter influenced all the other results. In the step of producing the sheets, the consistency of the mass was calculated and the same grammage ratios were used for all the papers.

For the determination of thickness, the micrometer was set at zero on the scale, the sample sheet was placed in position, and the movable disk was lowered until it rested on the paper sheet. The method provided resolution of $5 \mu \mathrm{m}$ and accuracy of $\pm 2.5 \mu \mathrm{m}$. The procedure was performed in triplicate, according to the methodology described in ABNT NBR NM ISO 534 (ABNT, 2006b).

\subsection{Measurements of opacity and porosity}

For determination of opacity, the paper sample was placed on a flat ceramic surface and the reading was obtained using a diffuse reflectance instrument, with resolution of $1 \%$ and accuracy of $+/-5 \%$ (absolute value on the percentage scale of the instrument). The procedure was performed in triplicate, following the methodology described in ABNT NBR NM ISO 2471 (ABNT, 2001a).

The porosity of the paper was determined by the Gurley method, as described in ABNT NBR NM ISO 5636-5 (ABNT, 2006c). The sample was placed between the discs, the system was sealed, and the time was adjusted in order to allow the passage of $100 \mathrm{~mL}$ of air, followed by reading the value on the instrument display. The procedure was performed in triplicate.

\subsection{Tearing resistance, wet and dry tensile strength, and humidity content}

The tearing resistance of the paper was determined using a dynamometer coupled to a guillotine, adjusted as described in ABNT NBR NM ISO 1974 (ABNT, 2001b). The paper sample was folded in two parts and positioned in the equipment, with subsequent activation of the trigger to release the counterweight (pendulum) and produce the tear. On the return, the guillotine was locked so that there was no change in the position of the pointer. The pointer indicated the reading on a graduated scale. The procedure was performed in triplicate. The tests were performed in two directions, longitudinal (LO) and transversal (TR), considering the fiber alignments in the prepared sheets.

The tests of wet and dry tensile strength were performed using a dynamometer with accuracy of $\pm 0.1 \mathrm{kgf}$ between 0 and $5.9 \mathrm{kgf}$, and $\pm 0.2 \mathrm{kgf}$ above $5.0 \mathrm{kgf}$. The tests were performed according to ABNT NBR NM ISO 14874 (ABNT, 2008) and ABNT NBR NM ISO 1924-1 (ABNT, 2001c), respectively. For the wet test, the specimen was immersed for $20 \pm 2 \mathrm{~s}$ in a vessel containing distilled water, after which it was placed between sheets of absorbent paper and pressure was applied to remove excess water. The specimen was placed in the dynamometer, avoiding touching the area positioned between the fixing grips. The pendulum hook was released and the load was applied by pressing the control lever. The reading indicated by the pointer on the strength scale was recorded as soon as rupture of the specimen occurred. The procedure was performed in triplicate.

The moisture content (as a percentage, on a wet basis) of the paper was determined by weighing the specimen and then placing it in an oven at $105 \pm 3{ }^{\circ} \mathrm{C}$ for at least $30 \mathrm{~min}$, until constant mass, followed by weighing it again. The procedure was performed in triplicate. The methodology followed the procedure described in ABNT NBR NM ISO 287 (ABNT, 2012).

\subsection{Statistical analysis of the results}

Statistical analysis (ANOVA) was performed after confirming the normality and homoscedasticity of the data. When differences were observed for the treatments $(F ; p \leq 0.05)$, the Tukey test $(p \leq 0.05)$ was used to evaluate the means (Box et al., 2005). 
Table 1 - Measured properties of the paper samples produced using the different fiber sources.

Tabela 1 - Resultados das propriedades obtidas dos testes realizados nas amostras de papel produzidas.

\begin{tabular}{|c|c|c|c|c|c|c|}
\hline \multirow{2}{*}{ Properties } & & \multirow{2}{*}{ Units } & \multicolumn{4}{|c|}{ Samples } \\
\hline & & & 1 & 2 & 3 & 4 \\
\hline Grammage & & $\mathrm{g} \mathrm{m}^{-2}$ & $120.67 \pm 3.21$ & $122.40 \pm 1.04$ & $121.70 \pm 1.05$ & $125.37 \pm 2.02$ \\
\hline Thickness & & $\mathrm{mm}$ & $2.42 \pm 0.02$ & $2.16 \pm 0.03$ & $2.35 \pm 0.12$ & $2.29 \pm 0.03$ \\
\hline Opacity & & $\%$ & $90.66 \pm 0.57$ & $87.63 \pm 1.33$ & $88.16 \pm 1.94$ & $83.53 \pm 3.75$ \\
\hline Porosity & & $\mathrm{s} 100 \mathrm{~cm}^{-3}$ & $2.41 \pm 0.03$ & $6.00 \pm 0.11$ & $5.12 \pm 0.65$ & $8.43 \pm 0.50$ \\
\hline Tearing & LO & $\mathrm{mN} \mathrm{m} \mathrm{m}^{2} \mathrm{~g}^{-1}$ & $14.43 \pm 0.30$ & $19.16 \pm 0.11$ & $16.16 \pm 0.21$ & $23.67 \pm 0.77$ \\
\hline resistance & TR & $\mathrm{mN} \mathrm{m} \mathrm{m}^{2} \mathrm{~g}^{-1}$ & $15.97 \pm 0.11$ & $23.16 \pm 0.05$ & $20.80 \pm 0.20$ & $25.40 \pm 1.04$ \\
\hline Wet tensile & LO & $\mathrm{mN} \mathrm{m} \mathrm{m}^{2} \mathrm{~g}^{-1}$ & $0.40 \pm 0.00$ & $0.23 \pm 0.05$ & $0.23 \pm 0.15$ & $0.23 \pm 0.15$ \\
\hline strength & TR & $\mathrm{mN} \mathrm{m}^{2} \mathrm{~g}^{-1}$ & $0.33 \pm 0.05$ & $0.20 \pm 0.00$ & $0.26 \pm 0.05$ & $0.30 \pm 0.00$ \\
\hline Dry tensile & LO & $\mathrm{mN} \mathrm{m} \mathrm{m}^{2} \mathrm{~g}^{-1}$ & $8.50 \pm 0.20$ & $4.83 \pm 0.05$ & $3.40 \pm 0.36$ & $6.06 \pm 0.05$ \\
\hline strength & TR & $\mathrm{mN} \mathrm{m}^{2} \mathrm{~g}^{-1}$ & $5.50 \pm 0.00$ & $6.50 \pm 0.17$ & $4.10 \pm 0.43$ & $4.90 \pm 0.20$ \\
\hline Moisture content & & $\%$ & $6.06 \pm 0.05$ & $7.23 \pm 0.05$ & $6.73 \pm 0.21$ & $7.56 \pm 0.05$ \\
\hline
\end{tabular}

Sample 1: 100\% Eucalyptus cellulose; sample 2: 100\% sugarcane bagasse cellulose; sample 3: 75\% Eucalyptus cellulose $+25 \%$ Pinus cellulose; sample 4: 75\% sugarcane bagasse cellulose $+25 \%$ Pinus cellulose.

\section{RESULTS}

In this work, comparative tests were performed using papers produced using the fibers obtained from Eucalyptus, Pinus, and sugarcane bagasse. The average parameter values obtained in the tests employing the paper samples are shown in Table 1.

Statistical analysis of the data was performed to evaluate differences between the samples. Results without statistical significance or with low significance are not presented.

The porosity values of the samples followed the order $4>2=3>1$ (Figure 1).

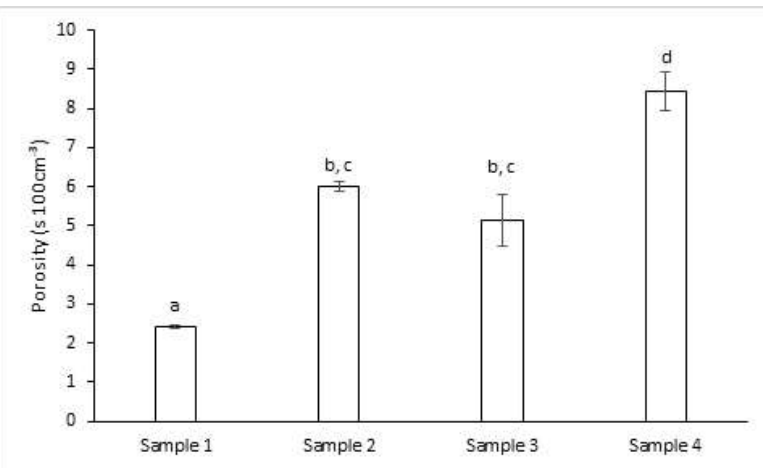

Figure 1 - Porosity of the paper samples. Groups with the same letter are not significantly different (Tukey's test, $\mathrm{p}>0.05$ ).

Figura 1 - Porosidade das amostras de papel. Grupos que compartilham a mesma letra não diferem (Tukey, $p>$ $0,05)$.
The same trend was observed for the tearing resistance, with the results for both $\mathrm{LO}$ and TR directions showing the highest values for sample 4, followed by samples 2, 3, and 1 (Figure 2). These results indicated that the porosity of the paper had little influence on the tearing resistance.

In contrast, in the dry tensile strength tests, sample 1 showed the highest strength in the LO direction, followed by samples 4, 2, and 3 (Figure 3 ). No significant differences between the sample groups were observed in the wet tensile strength tests.

The values obtained in the moisture analyses followed the same order observed for porosity and

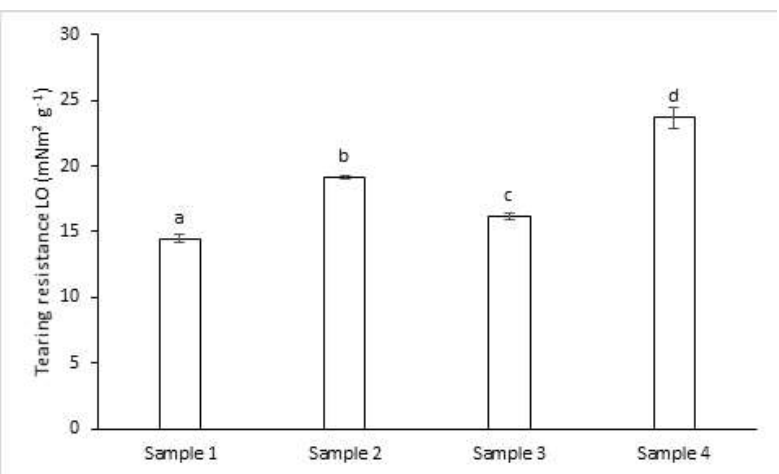

Figure 2 - Tearing resistance of the paper samples in the longitudinal (LO) direction. Groups with the same letter are not significantly different (Tukey's test, $\mathrm{p}>0.05$ ).

Figura 2 - Resistência ao rasgo no sentido longitudinal (LO) das amostras de papel. Grupos que compartilham a mesma letra não diferem(Tukey, $p>0,05$ ). 


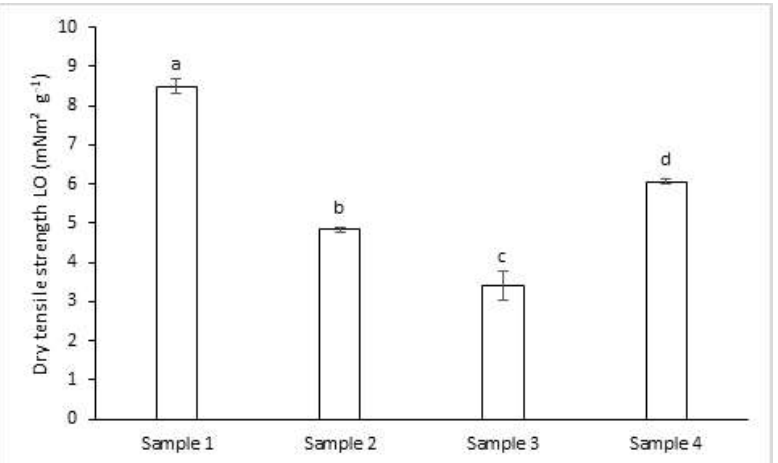

Figure 3 - Dry tensile strength of the paper samples in the longitudinal (LO) direction. Groups with the same letter are not significantly different (Tukey's test, $\mathrm{p}>0.05$ )

Figura 3 - Resistência à tração seca no sentido longitudinal (LO) das amostras de papel. Grupos que compartilham a mesma letra não diferem (Tukey, $p>0,05$ ).

the LO and TR tearing resistances, with sample 4 presenting the highest moisture content, followed by samples 2, 3, and 1 (Figure 4).

\section{DISCUSSION}

The findings showed that the paper composed only of Eucalyptus fibers was the least porous, while mixing these fibers with those of Pinus, at a ratio of $3: 1$, resulted in porosity similar to that for the paper composed only of sugarcane bagasse fibers. The highest porosity was shown by the paper composed of a 3:1 mixture of sugarcane bagasse and Pinus fibers, which could lead to low permeability of the paper. Highly porous papers are used in

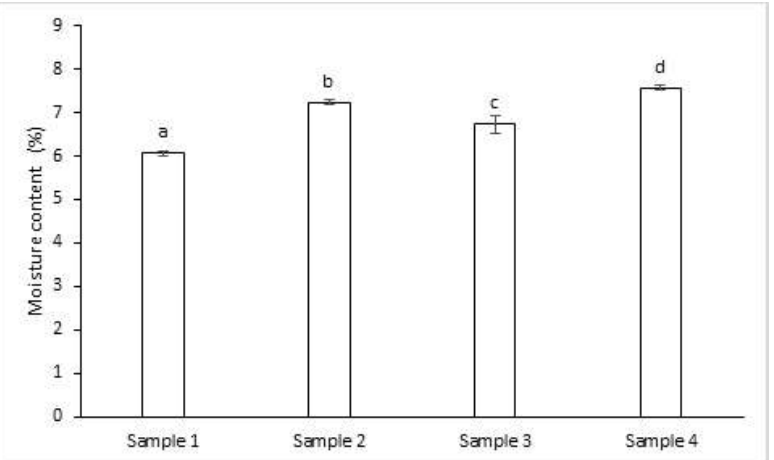

Figure 4 - Moisture contents of the paper samples. Groups with the same letter are not significantly different (Tukey's test, $p>0.05$ )

Figura 4 - Teor de umidade das amostras de papel. Grupos que compartilham a mesma letra não diferem (Tukey, $\mathrm{p}>$ $0,05)$. biological assays, as alternatives to nitrocellulose and microcapillary membranes (Hansson et al., 2016), indicating a possible use for this paper. However, the paper obtained using 100\% sugarcane bagasse fiber (sample 2) presented porosity similar to that of the traditional paper produced using a mixture of Pinus and Eucalyptus (sample 3).

The resistance of the paper to tearing and stretching was related to the length of the fibers that composed it. Longer fibers result in stronger paper, while some studies have found that thinner fibers provide greater strength, compared to thicker fibers (Seth, 1996; Yu, 2001; Hiltunen and Paulapuro, 2011).

In the tearing resistance tests, a synergistic effect was observed for the mixture of the short fibers of sugarcane bagasse with the long fibers of Pinus (sample 4). This was not observed for the mixture of Eucalyptus and Pinus fibers (sample 3). Considering the samples consisting of $100 \%$ shorter fibers, the paper produced using sugarcane bagasse (sample 2) presented higher tearing resistance, compared to the paper obtained using Eucalyptus fibers (sample 1), indicating that fiber length alone could not explain the resistance characteristics (Andrade et al., 2013). This was supported by the results of the dry tensile strength tests, where the paper with the highest strength was composed of $100 \%$ short fibers (sample 1). No significant differences among the samples were found in the wet tensile strength tests.

The tensile strength of paper is also influenced by the elastic modulus, which is not governed by the fiber length, but rather by effects related to specific fiber segments, involving interfiber bonding and fiber strength (Hiltunen et al., 2002).

\section{CONCLUSIONS}

The results indicated that sugarcane bagasse is a promising material for use in the paper industry. The paper obtained by replacing Eucalyptus fibers with sugarcane bagasse fibers presented improved characteristics in terms of tearing resistance and tensile strength, as well as porosity and moisture content.

Considering these findings and the widespread availability of sugarcane bagasse in Brazil, further studies should be conducted with the aim of using these fibers for applications in the paper industry. 


\section{REFERENCES}

Andrade AS, Hernandez JA, Klock U. Polpa e Papel [Internet]. 2013. [cited August 20, 2019]. Available at: http://www.madeira.ufpr.br/disciplinasklock/ polpaepapel/manualpolpa2013.pdf

Associação Brasileira de Normas Técnicas - ABNT. NBR ISO - 14874: Pasta celulósica - Determinação da resistência à tração zero-span, a úmido ou a seco. Rio de Janeiro: 2008.

Associação Brasileira de Normas Técnicas - ABNT. NBR ISO - 5269-1: Pastas celulósicas - Preparação de folhas em laboratório para ensaios físicos - Parte 1: Método do formador de folhas convencional. Rio de Janeiro: 2006a.

Associação Brasileira de Normas Técnicas - ABNT. NBR ISO - 534: Papel e cartão - Determinação da espessura, densidade e volume específico. Rio de Janeiro: 2006b.

Associação Brasileira de Normas Técnicas - ABNT. NBR ISO - 5636-5: Papel e cartão - Determinação da permeância e resistência ao ar (faixa média) Parte 5: Método Gurley. Rio de Janeiro: 2006c.

Associação Brasileira de Normas Técnicas - ABNT. NBRNM ISO - 536: Papel e cartão - Determinação da gramatura. Rio de Janeiro: 2002.

Associação Brasileira de Normas Técnicas ABNT. NBRNM ISO - 2471: Papel e cartão - Determinação da opacidade (fundo de papel) - Método da reflectância difusa. Rio de Janeiro: 2001a.

Associação Brasileira de Normas Técnicas - ABNT. NBRNM ISO - 1974: Papel - Determinação da resistência ao rasgo - Método Elmendorf. Rio de Janeiro: 2001b.

Associação Brasileira de Normas Técnicas ABNT. NBRNM ISO - 1924-1: Papel e cartão Determinação das propriedades de tração - Parte 1: Método da velocidade constante de carga. Rio de Janeiro: 2001c.

Associação Brasileira de Normas Técnicas - ABNT. NBRNM ISO - 287: Papel e cartão - Determinação do teor de umidade de um lote - Método por secagem em estufa. Rio de Janeiro: 2012.
Associação dos Registradores Imobiliários de São Paulo - ARISP. Relatório de sustentabilidade [Internet]. 2018. [cited August 20, 2019]. Available at: https://s3-us-west-2.amazonaws.com/ungcproduction/attachments/cop_2018/470192/original/ Relat\%C3\%B3rio_Sustentabilidade_ARISP_2018. pdf? 1544554898

Borsato R, Kauchakje S, Rochadelli R. Rede de responsabilidade socioambiental: uma metodologia para análise no setor de celulose e papel. Revista Árvore. 2010;34(2):355-65.

Box GEP, Hunter JS, Hunter WG. Statistics for experiments: design, innovation, and discovery. 2 nd. New Jersey: Wiley-Interscience; 2005. ISBN 13978047171813-0.

Castro HF. Papel e celulose. Curso de processos químicos industriais II- Apostila 4 [Internet].

2009. [cited August 20, 2019]. Available at: https:// sistemas.eel.usp.br/docentes/arquivos/5840556/434/ apostila4papelecelulose.pdf

Departamento de Pesquisas e Estudos Econômicos do Banco Bradesco - DEPEC. Papel e Celulose [Internet]. 2017. [cited August 20, 2019]. Available at: https://www.economiaemdia.com.br/ EconomiaEmDia/pdf/infset_acucar_etanol.pdf

Hansson J, Yasuga H, Haraldsson T, van der Wijngaart W. Synthetic microfluidic paper: high surface area and high porosity polymer micropillar arrays. Lab Chip. 2016;16(2):298-304.

Hiltunen EJ, Kettunen H, Laine JE, Paulapuro $\mathrm{H}$. Behaviour of reinforcement fibres in TMPbased paper. Paperi Ja Puu-Paper and Timber. 2002;84(4):269-273.

Hiltunen E, Paulapuro H. Effect of long-fibred reinforcement pulp on mechanical properties of short fibred-based paper. O Papel. 2011;72(8):42-48.

Indústria Brasileira de Árvores - IBÁ. Relatório anual [Internet]. 2016. [cited August 20, 2019]. Available at: http://iba.org/images/shared/Biblioteca/ IBA_RelatorioAnual2016_.pdf

Maranesi GL. Influência de variáveis do processo de produção industrial na qualidade da polpa Kraft de eucalipto [dissertação]. Viçosa (MG): Universidade

Revista Árvore 2019;43(4):e430411 
Federal de Viçosa; 2010.

Miranda RES. Impactos ambientais decorrentes dos resíduos gerados na produção de papel e celulose [monografia em engenharia florestal]. Seropédica (RJ): Universidade Federal Rural do Rio de Janeiro; 2008.

Salles TT, Silva ML, Soares NS, Moraes AC.

Exportação brasileira de papel e celulose: sua dinâmica pela equação gravitacional. Revista Árvore. 2011;35(3):573-580.

Seth RS. Optimizing reinforcement pulps by fracture toughness. TAPPI Journal. 1996;79(1):170-78.

Yu Y. The effect of fiber raw material on some toughness properties of paper [dissertation]. Helsinki, Finland: Helsinki University of Technology; 2001. 